\title{
Performance Analysis of a 50 Kw Pv Plant IN TOMISLAVGRAD
}

\author{
Marin Bakula \& Nikola Kulušić
}
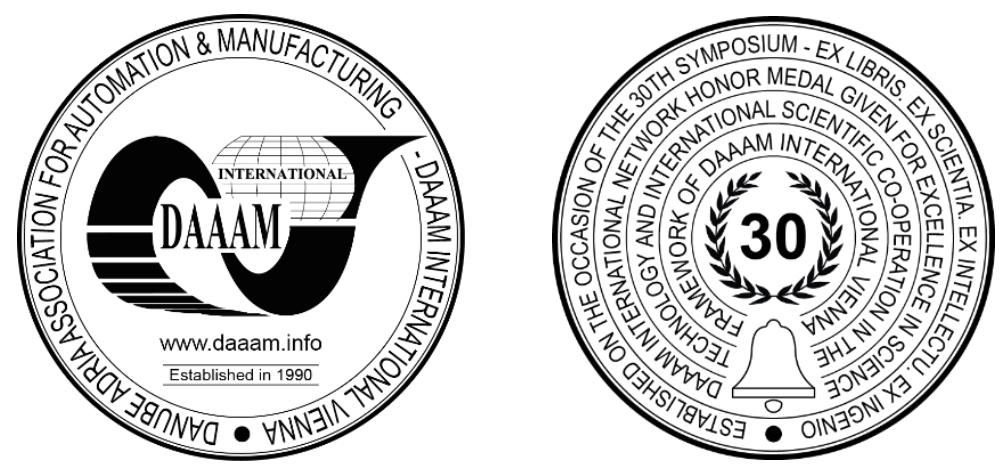

This Publication has to be referred as: Bakula, M[arin] \& Kulusic, N[ikola] (2020). Performance Analysis of a $50 \mathrm{Kw}$ PV Plant in Tomislavgrad, Proceedings of the 31st DAAAM International Symposium, pp.0868-0876, B. Katalinic (Ed.), Published by DAAAM International, ISBN 978-3-902734-29-7, ISSN 1726-9679, Vienna, Austria

DOI: $10.2507 / 31$ st.daaam.proceedings. 121

\begin{abstract}
The article presents technical description and performance analysis of a $50 \mathrm{~kW}$ solar PV plant installed on a business facility of JP Elektroprivreda HZ HB in Tomislavgrad (Bosnia and Herzegovina). The experimental data were recorded from 1st January 2019 to 31st December 2019 based on real time measurements. In that period, the annual PV system production was 63.126 $\mathrm{MWh}$ and average horizontal global irradiation at the location in 2019 was found 4.13 $\mathrm{kWh} / \mathrm{m} 2 /$ day. The monthly final yield, reference yield and performance ratio have been found to vary from 16.69 $\mathrm{kWh} / \mathrm{kWp}$ to $177.71 \mathrm{kWh} / \mathrm{kWp}, 63.64 \mathrm{kWh} / \mathrm{kWp}$ to $214.48 \mathrm{kWh} / \mathrm{kWp}$ and $26 \%$ to $92 \%$ respectively. The annual average capacity factor and overall system efficiency were found to be $14.2 \%$ and $14.8 \%$ respectively. The paper shows good potential for integration of PV system in this part of Bosnia and Herzegovina and it can be useful to engineers, researchers and investors.
\end{abstract}

Keywords: PV plant; performance analysis; efficiency.

\section{Introduction}

Solar energy is an extremely potential source of primary energy. For years, this type of primary energy has been unused due to high investment and operating costs and economic unprofitability of investment. The introduction of incentive schemes has led to significant exploitation of this source and investment in power plants based on the conversion of solar energy into electricity. Photovoltaic (PV) power plants are used for mass production of electricity, which is transmitted and distributed to every consumer via the electricity network. Unlike a stand-alone or island system in which the produced electricity is most often stored in batteries, a photovoltaic power plant or a solar photovoltaic power plant is a system that is connected to the grid, i.e. it transmits all produced electricity to the electricity system. They represent one of the most elegant ways to use solar energy, and their work is based on the photovoltaic effect.

In past decade, PV systems for electricity production are having significant growth all over the world. According to [1], total cumulative installed capacity at the end of 2019 globally amounted to at least $627 \mathrm{GW}$. China has cumulative capacity $204,7 \mathrm{GW}$, followed by the European Union (131.3 GW), the USA (75.9 GW), Japan (63.0 GW) and India (42.8 $\mathrm{GW}$ ) [1]. In the Asia-Pacific region, Australia reached 14.6 GW and Korea 11.2 GW. In the European Union, Germany leads with $49.2 \mathrm{GW}$, followed by Italy $(20.8 \mathrm{GW})$ and the UK (13.3 GW) [1]. Figure 1 shows evolution of regional PV installations in past 20 years in the world. 


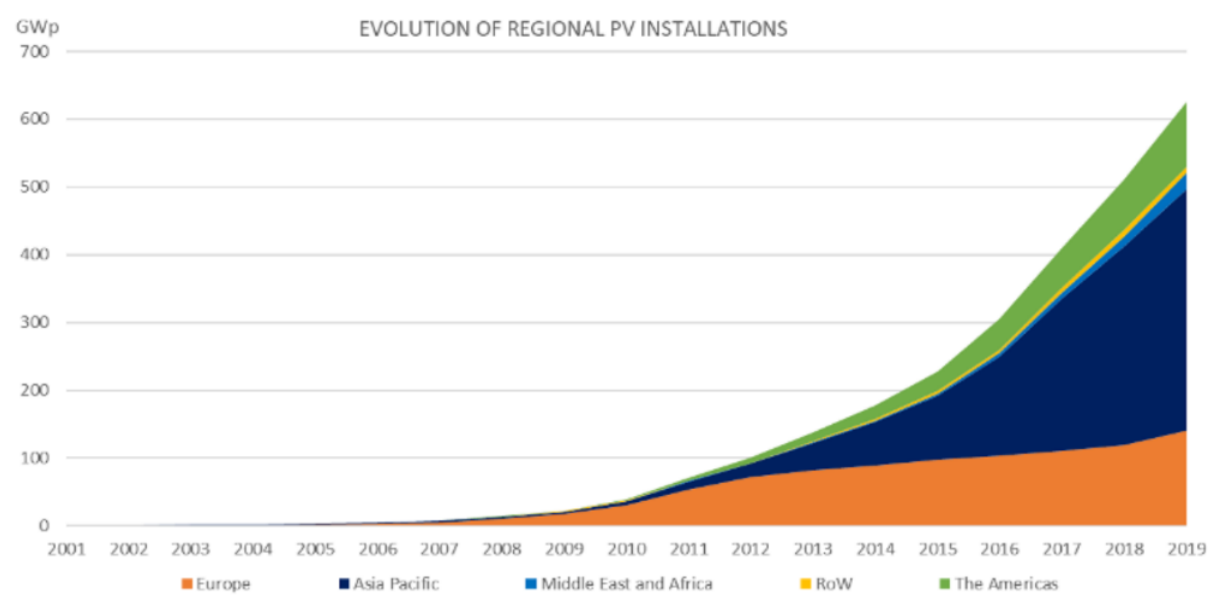

Fig. 1. Evolution of regional PV installations, Source IEA PVPS [1]

As it is shown, Europe was leader in PV installations by 2012 when Asia, leaded by China, India, Japan, Korea and others, started to grow fast and continues to grow still. Growth of PV installations is significant all over the world and Bosnia and Herzegovina follows that trend also. Figure 1 shows the regional potential of Europe in terms of global solar radiation in $\mathrm{kWh} / \mathrm{m}^{2}$. Bosnia and Herzegovina can be counted among more favourable locations in Europe with solar irradiation figures on horizontal surface of $1240 \mathrm{kWh} / \mathrm{m}^{2}$ in the north of the country, and up to $1600 \mathrm{kWh} / \mathrm{m}^{2}$ in the south.

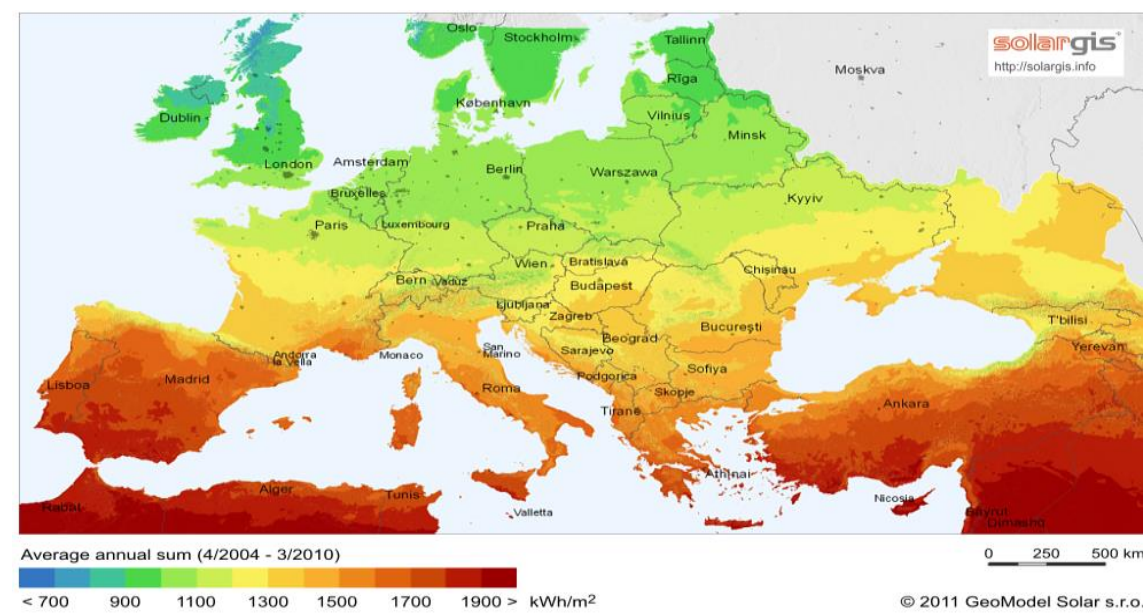

Fig. 2. Global horizontal irradiance in Europe, source SOLARGIS

Growth of PV installations in Bosnia and Herzegovina started in 2012 when the first PV systems were installed. According to [3] there were 22.35 MW of PV installations in 2019 in Bosnia and Herzegovina with growth of 4.2 MW comparing to 2018. In next period it is expected to have a bigger growth in PV systems, so the system performance is very important for potential investors and system designers.

The municipality of Tomislavgrad, where the PV system is installed, is located at about $900 \mathrm{~m}$ above sea level in south part of Bosnia and Herzegovina and is characterized by a plain field, mountain area, rivers, lakes, forests, pastures and karst, and the climate is continental with mean annul ambient temperature round $10{ }^{\circ} \mathrm{C}$. This area is also characterized by snowfalls in period December to February.

The analysis presented in [5] shows the potential for usage of solar energy in Sarajevo, since the Tomislavgrad area is located further south, it has a greater potential for installation of PV systems. Therefore, the main goal of this paper is to show potential for PV systems usage through performance analysis of PV system in Tomislavgrad which can be used by PV system designers, potential investors and researchers.

\section{Description of PV plant and approach}

Photovoltaic (PV) plant $50 \mathrm{~kW}$ is part of building microgrid equipment (together with autonomous $32 \mathrm{~kW}$ battery system and building as $130 \mathrm{~kW}$ load) at building facility of Production Division EP HZ HB in Tomislavgrad which was equipped through the EU project Smart Building - Smart Grid - Smart City (3Smart), financed by European Union funds (ERDF, IPA) from the Interreg Danube Transnational Programme [3]. 
The PV plant is installed on the two parking constructions near the main building ( $2 \times 69$ modules, tilt $\left.15^{\circ}\right)$, as well as on the roof of auxiliary object ( 28 modules, tilt $27^{\circ}$ ). Rated power of PV plant is $49.8 \mathrm{kWp}$, there are installed 166 solar modules type Eurener type MVEP 300 (Figure 1). The modules are connected to three DC/AC inverters; two of them with nominal power of $20 \mathrm{~kW}$, type Fronius Symo 20.0.-3M and one with nominal power of $10 \mathrm{~kW}$, type Fronius Symo 10.0.-3M. The geographical location of the site is $43.679847^{\circ}\left(43^{\circ} 40^{\prime} 47.45^{\prime \prime} \mathrm{N}\right)$ Latitude and $17.200731^{\circ}\left(17^{\circ} 12^{\prime} 2.63^{\prime \prime} \mathrm{E}\right)$ Longitude with module orientation of $63^{\circ}$ from South. Site elevation is $861 \mathrm{~m}$.

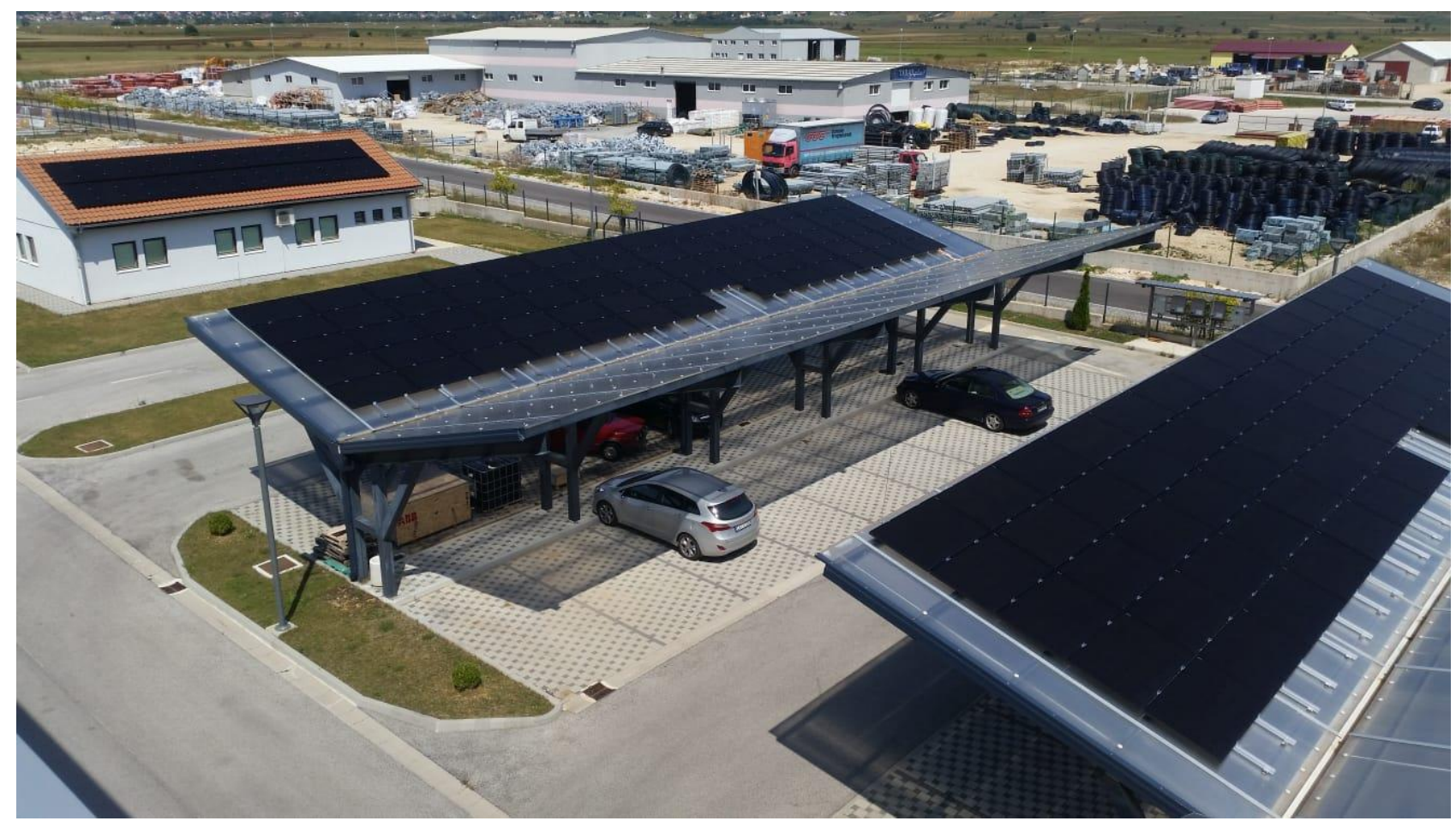

Fig. 3. $50 \mathrm{~kW}$ PV plant in Tomislavgrad [3]

Technical characteristics of the MEPV 300 solar module - dimensions of 1640 x 992 x $40 \mathrm{~mm}$, surface of $1.627 \mathrm{~m}^{2}(\mathrm{PV}$ module area) in Standard Test Conditions, STC $\left(\mathrm{T}=25^{\circ} \mathrm{C}, \mathrm{I}=1000 \mathrm{~W} / \mathrm{m}^{2}\right)$ are given in Table 1.

\begin{tabular}{|c|c|}
\hline Solar module & $\begin{array}{c}\text { Monocrystalline } \\
\text { silicon }\end{array}$ \\
\hline Model & MEPV 300 \\
\hline Maximum power at STC (Pmax) & $300 \mathrm{~W}$ \\
\hline Open circuit voltage (Voc) & $39.75 \mathrm{~V}$ \\
\hline Short circuit current (Isc) & $9.89 \mathrm{~A}$ \\
\hline Optimum power voltage (Vmp) & $32.02 \mathrm{~V}$ \\
\hline Optimum operating current (Imp) & $9.37 \mathrm{~A}$ \\
\hline Temperature coefficients of Voc & $-0.29 \% /{ }^{\circ} \mathrm{C}$ \\
\hline Temperature coefficients of Isc & $0.039 \% /{ }^{\circ} \mathrm{C}$ \\
\hline Temperature coefficients of Pmax & $-0.42 \% /{ }^{\circ} \mathrm{C}$ \\
\hline Number of cells & 60 \\
\hline
\end{tabular}

Table 1. Technical characteristics of the solar module Eurener MEPV 300

Technical characteristics of the DC/AC inverters are given in Table 2. 


\begin{tabular}{|c|c|c|}
\hline INPUT DATA (DC) & Symo 10.0.3-M & Symo 20.0.3-M \\
\hline Number of MPP trackers & 2 & 2 \\
\hline Max. Input voltage (DC) & $1000 \mathrm{~V}$ & $1000 \mathrm{~V}$ \\
\hline MPP voltage range ( $\left.U_{m p p \min }-U_{m p p \max }\right)$ & $270-800 \mathrm{~V}$ & $420-800 \mathrm{~V}$ \\
\hline Feed-in start voltage $\left(\mathrm{U}_{\mathrm{dc}}\right.$ start $)$ & 200 & $200 \mathrm{~V}$ \\
\hline Max. input current $\left(\mathrm{I}_{\mathrm{dc} \max }\right)$ & $27.0 / 16.5 \mathrm{~A}$ & $33.0 / 27.0 \mathrm{~A}$ \\
\hline Max. $\mathrm{PV}$ generator power $\left(\mathrm{P}_{\mathrm{dc} \max }\right)$ & $15 \mathrm{~kW}_{\text {peak }}$ & $30 \mathrm{~kW}_{\text {peak }}$ \\
\hline Number of DC connections & $3+3$ & $3+3$ \\
\hline OUTPUT DATA (AC) & Symo 10.0.3-M & Symo 20.0.3-M \\
\hline AC nominal output $\left(\mathrm{P}_{\text {ac. }}\right)$ & $10 \mathrm{~kW}$ & $20 \mathrm{~kW}$ \\
\hline Max. output power $\left(\mathrm{P}_{\mathrm{ac} \max }\right)$ & $10 \mathrm{kVA}$ & $20 \mathrm{kVA}$ \\
\hline AC output current $\left(\mathrm{I}_{\mathrm{ac} \text { nom }}\right)$ & $14.4 \mathrm{~A}$ & $28.9 \mathrm{~A}$ \\
\hline Grid connection $\left(\mathrm{U}_{\text {ac. }}\right)$ & $\begin{array}{c}3 \sim \mathrm{NPE} \\
\text { 400/230, 3 } \\
\text { NPE 380/220 V }\end{array}$ & $\begin{array}{c}3 \sim \text { NPE 400/230, } \\
3 \sim \text { NPE 380/220 } \\
\mathrm{V}\end{array}$ \\
\hline AC voltage range $\left(U_{\min }-U_{\max }\right)$ & $150-280 \mathrm{~V}$ & $150-280 \mathrm{~V}$ \\
\hline Frequency $\left(\mathrm{f}_{\mathrm{r}}\right)$ & $50 / 60 \mathrm{~Hz}$ & $50 / 60 \mathrm{~Hz}$ \\
\hline Frequency range $\left(f_{\min }-f_{\max }\right)$ & $50 / 60 \mathrm{~Hz}$ & $50 / 60 \mathrm{~Hz}$ \\
\hline Power factor $\left(\cos \varphi_{\mathrm{ac}, \mathrm{r}}\right)$ & 0-1 ind./cap. & 0-1 ind./cap. \\
\hline Total harmonic distortion & $1.8 \%$ & $1.3 \%$ \\
\hline $\begin{array}{c}\text { Max. efficiency (PV - grid)/ European } \\
\text { efficiency }(\eta \mathrm{EU})\end{array}$ & $\begin{array}{c}98 \% / 97.4 \%( \\
\left.\eta_{\mathrm{EU}}\right)\end{array}$ & $\begin{array}{c}98.1 \% / 97.9 \%( \\
\left.\eta_{\mathrm{EU}}\right)\end{array}$ \\
\hline
\end{tabular}

Table 2. Technical characteristics of the inverters Fronius Symo 10.0.3-M, and Symo 20.0.3-M

For measuring electrical consumption of building, major consumers in the building, measurements from production of photovoltaic cells and battery storage system the new energy meters were installed. For PV plant energy production measurement (integrated in AC cabinet) energy meter Siemens type Sentron PAC3200 with PAC Modbus RTU was installed, Figure 2. Measurements from energy meter are stored in database at 1-minute scale.

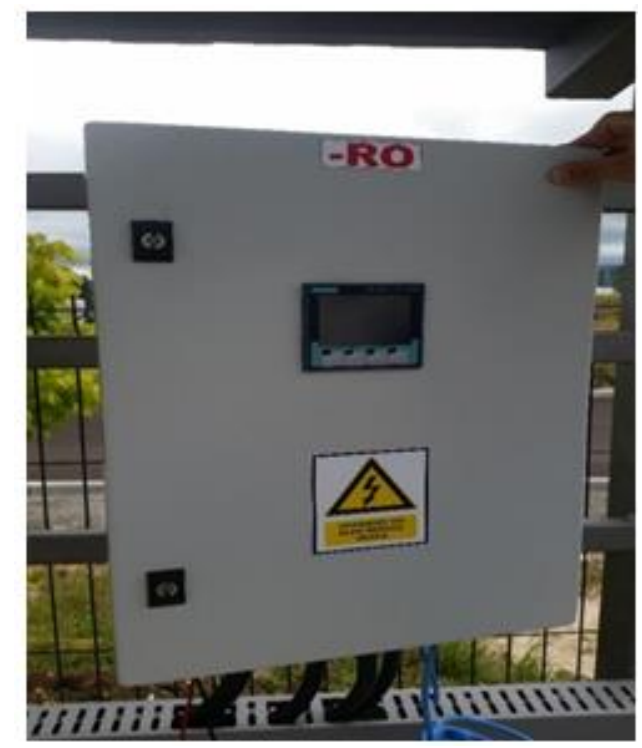

Fig. 4. Siemens SENTRON PAC3200

For PV plant monitoring and energy management the Fronius Solar.Web system is used, PV production is also available from this system. For global horizontal solar irradiance measurements, two pyranometers KIPP \& ZONEN type SMP6-V were installed on a parking construction, one by angle $0^{\circ}$ and other by $27^{\circ}$. A pyranometer is a radiometer designed for measuring the irradiance in $\mathrm{W} / \mathrm{m}^{2}$ resulting from radiant fluxes incident upon a plane surface (horizontal or tilted) from the hemisphere above and integrated over a wavelength range of at least 300 to 3000 nanometers (nm) [15]. Technical specification of SMP6-V pyranometer are given in Table 3. 


\begin{tabular}{|c|c|}
\hline Classification to ISO 9060:2018 & Spectrally Flat Class B \\
\hline Analogue output $\bullet$ V-version & 0 to $1 \mathrm{~V}$ \\
\hline Analogue output range & -200 to $2000 \mathrm{~W} / \mathrm{m}^{2}$ \\
\hline Analogue output $\bullet$ A-version & 4 to $20 \mathrm{~mA}$ \\
\hline Analogue output range & RS-485 Modbus $1600 \mathrm{~W} / \mathrm{m}^{2}$ \\
\hline Serial output & -400 to $2000 \mathrm{~W} / \mathrm{m}^{2}$ \\
\hline Serial output range & 280 to $3000 \mathrm{~nm}$ \\
\hline Spectral range $(20 \%$ point) & 285 to $2800 \mathrm{~nm}$ \\
\hline Spectral range $(50 \%$ points) & $<1.5 \mathrm{~s}$ \\
\hline Response time $(63 \%)$ & $<12 \mathrm{~s}$ \\
\hline Response time $(95 \%)$ & $<10 \mathrm{~W} / \mathrm{m}^{2}$ \\
\hline Zero offset A & $<4 \mathrm{~W} / \mathrm{m}^{2}$ \\
\hline Zero offset B & $<15 \mathrm{~W} / \mathrm{m}^{2}$ \\
\hline Directional response (up to $80^{\circ}$ with $1000 \mathrm{~W} / \mathrm{m}^{2}$ beam) & $<3 \%$ \\
\hline Temperature dependence of sensitivity $\left(-40{ }^{\circ} \mathrm{C}\right.$ to $\left.+70{ }^{\circ} \mathrm{C}\right)$ & 4 to $20 \mathrm{~mA} / 0$ to $1 \mathrm{~V}$ \\
\hline Analogue output $(-\mathrm{A} / \mathrm{V}$ version) & 2 -wire RS-485 \\
\hline Digital output & \\
\hline
\end{tabular}

Table 3. Specifications of SMP6 Pyranometer [15]

Measurements from pyranometers are transferred to database at 1-minute scale, for PV plant evaluation measurements from horizontally placed pyranometer were used. Performance analysis for PV plant was carried out which can determine potential for electricity production of PV system in this area, which is the main output of this research. Real measurements, which were stored in database and averaged for every 1 hour during a typical day per month in the year 2019, were used. The main problem was the lack of data in certain periods due to server failure, however PV system production from Fronius Solar.Web system were used (5-min resolution, averaged for 1 hour) and estimation of ambient temperature and horizontal solar irradiance. Next research should be evaluation of PV plant dependence of electricity production to temperature and wind speed as and techno-economic analysis.

\section{PV system characteristic parameters for performance evaluation}

For evaluation of PV system performance, the final yield $\left(\mathrm{Y}_{\mathrm{F}}\right)$, the reference yield $\left(\mathrm{Y}_{\mathrm{R}}\right)$, the performance ratio $(\mathrm{PR})$ and the capacity factor (CF) were calculated as defined by the IEC Standard 61724 [6]. These parameters are commonly used in similar studies [7], [8], [9], [10], [11], [12] where the performance analysis of PV system was carried out.

\section{Final yield $\left(\mathbf{Y}_{\mathrm{F}}\right)$}

The final PV system yield $\mathrm{Y}_{\mathrm{f}}$ is the portion of the daily net energy output of the entire PV plant which was supplied by the array per $\mathrm{kW}$ of installed $\mathrm{PV}$ array [7]. The final yield $\left(\mathrm{Y}_{\mathrm{F}}\right)$ is defined as the annual, monthly or daily net $\mathrm{AC}$ (alternating current) energy output $\left(\mathrm{E}_{\mathrm{AC}}\right)(\mathrm{kWh})$ of the system divided by the peak power $\left(\mathrm{P}_{\mathrm{PV} r a t e d}\right)(\mathrm{kW})$ of the installed PV array at STC [8].

$$
Y_{F}=\frac{E_{A C}}{P_{P V \text { rated }}}
$$

\section{Reference yield $\left(\mathbf{Y}_{\mathbf{R}}\right)$}

This yield represents the number of hours per day during which the solar radiation would need to be at reference irradiance levels in order to contribute the same incident energy as was monitored. [7]. Reference yield is defined as the ratio of in-plane solar isolation $\left(\mathrm{H}_{\mathrm{t}}\right)\left(\mathrm{kWh} / \mathrm{m}^{2}\right)$ to the reference irradiance $(\mathrm{G})\left(1 \mathrm{~kW} / \mathrm{m}^{2}\right)[8]$ :

$$
Y_{R}=\frac{H_{t}}{G}
$$




\section{Performance ratio (PR)}

The performance ratio PR indicates the overall effect of losses on the array is rated output due to array temperature, incomplete utilization of the irradiation, and system component inefficiencies or failure [7]. PR indicates the closeness to the ideal efficiency of a PV system, for ideal PV system its value is 1 (100\%) which is not possible practically. It is the main feature of a grid connected PV system.

$$
P R=\frac{Y_{F}}{Y_{R}}
$$

\section{Capacity factor $(\mathbf{C F})$}

CF is the ratio of the energy output of a PV system for a year to the energy generated by the PV system if it operates for a year in a whole $24 \mathrm{~h}$ [8]. If the PV system produces full power continuously, it is a capacity factor will be unity. It is formulated as an equation:

$$
C F=\frac{E_{A C, \text { annual }}}{P_{P V \text { rated }} \cdot 8760}
$$

\section{Overall System Efficiency $\left(\boldsymbol{\eta}_{\mathrm{sys}, \mathrm{m}}\right)$}

The monthly overall system efficiency $\left(\eta_{\mathrm{sys}, \mathrm{m}}\right)$ is defined as the ratio of the monthly energy output of the system to the total energy collected from the PV field during a month [8].

$$
\eta_{\text {sys }, m}=\frac{E_{A C, \text { month }}}{H_{t} \cdot A_{P V \text { array }}}
$$

Where the parameters are:

$\mathrm{E}_{\mathrm{AC} \text {,month }}$ - monthly energy output - AC (kWh),

$\mathrm{H}_{\mathrm{t}}$ - total in plane solar insolation $\left(\mathrm{kWh} / \mathrm{m}^{2}\right)$,

APVarray - total area of the PV modules $\left(\mathrm{m}^{2}\right)$.

\section{Results and discussion}

PV system and meteorological parameters (PV production, ambient temperature, and solar irradiance) were measured in period 1.1. - 31.12.2019. Minimum value of monthly average of global horizontal irradiance was during November (1.43 $\mathrm{kWh} / \mathrm{m} 2 /$ day) and maximum during July $(6.93 \mathrm{kWh} / \mathrm{m} 2$ /day). The mean monthly daily ambient temperature, during the day hours when PV system produces energy, varied from $-1.7^{\circ} \mathrm{C}$ (January) to $23.9^{\circ} \mathrm{C}$ (June) as shown in Table 4.

\begin{tabular}{|c|c|c|c|}
\hline Month & $\begin{array}{c}\text { Horizontal global irradiance } \\
(\mathbf{W} / \mathbf{m} \mathbf{2}) \mathbf{- m e a s u r e d}\end{array}$ & $\begin{array}{c}\text { Daily horizontal global } \\
\text { irradiation }\left(\mathbf{k W h} / \mathbf{m}^{\mathbf{2}} / \mathbf{d a y}\right)\end{array}$ & $\begin{array}{c}\text { Ambient daily } \\
\text { temperature }\left(\mathbf{0}^{\mathbf{C}}\right)\end{array}$ \\
\hline January & 85.64 & 2.05 & -1.70 \\
\hline February & 128.30 & 2.90 & 2.62 \\
\hline March & 201.60 & 4.73 & 11.78 \\
\hline April & 199.20 & 4.77 & 11.33 \\
\hline May & 168.91 & 3.93 & 22.63 \\
\hline June & 286.85 & 6.26 & 23.22 \\
\hline July & 264.81 & 6.93 & 19.33 \\
\hline August & 277.90 & 5.83 & 14.40 \\
\hline September & 206.38 & 4.91 & 9.80 \\
\hline October & 126.17 & 4.18 & 4.07 \\
\hline November & 59.43 & 1.43 & 12.41 \\
\hline December & 58.63 & 1.57 & \\
\hline Average & 171.99 & 4.13 & \\
\hline
\end{tabular}

Table 4. Metrological measurements for PV system location in 2019.

Mean ambient temperature for location in Tomislavgrad during the year 2019 was $10.46{ }^{\circ} \mathrm{C}$ and average of horizontal global irradiation at the location in 2019 was found $4.13 \mathrm{kWh} / \mathrm{m}^{2} /$ day $\left(1.517,92 \mathrm{kWh} / \mathrm{m}^{2} /\right.$ day in total). The PV system generated 63.126 MWh electrical energy in 2019, which is close to expected energy production of system 64.201 MWh (simulation in PVSyst), Figure 5. In October 2019, due to a failure in the PV panel the 10-kW inverter was out, so the production for October, November and December 2019 is slightly lower than possible. 


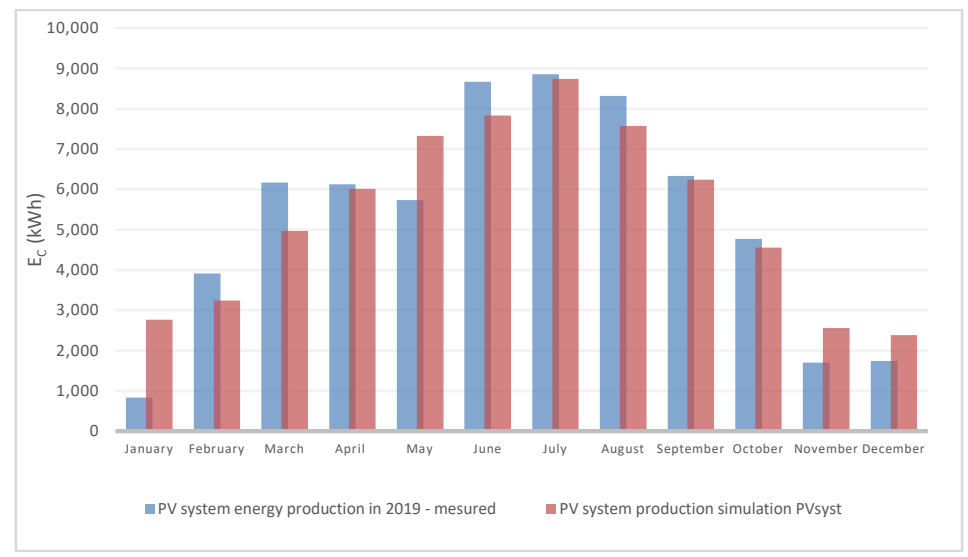

Fig. 5. PV system energy production in 2019 (measured) and production simulation results

Maximum production was recorded in July (8.85 MWh) and minimum in January (0.831 MWh). Lower production of PV system in January is the result of heavy snowfall in that period, which is certainly a characteristic of this part of the year in the area of Tomislavgrad. It is the snowfall in January and February that is one of the factors that should be considered when planning the PV system in this climate area. For PV system mounted on roofs in this climate area, electricity in January and February could be much lower than expected due to snowfall. Monthly averaged daily final and reference yield are shown on Figure 6. Average monthly reference yield was $126.49 \mathrm{kWh} / \mathrm{kWp}$ and average final yield was $105.69 \mathrm{kWh} / \mathrm{kWp}$. The lowest value of final yield $16.69 \mathrm{kWh} / \mathrm{kWp}$ was observed in January because of heavy snowfall in that period and highest at July 2019.

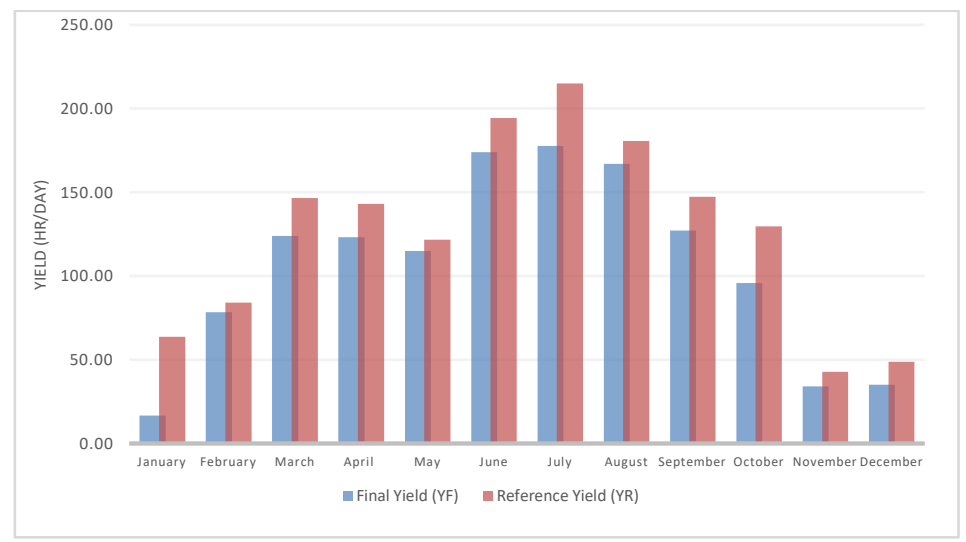

Fig. 6. Monthly averaged daily Final and Reference yield

Performance ratio determines the performance of the $50 \mathrm{~kW}$ solar PV system in the actual climate compared to performance at STC. Figure 7 shows that monthly values for the PR of the $50 \mathrm{~kW}$ solar PV system on the EP HZ HB building in Tomislavgrad ranged from $0.26(26 \%)$ in January to $0.92(92 \%)$ in July 2019. The average annual performance ratio of the PV system in 2019 was 0.8.

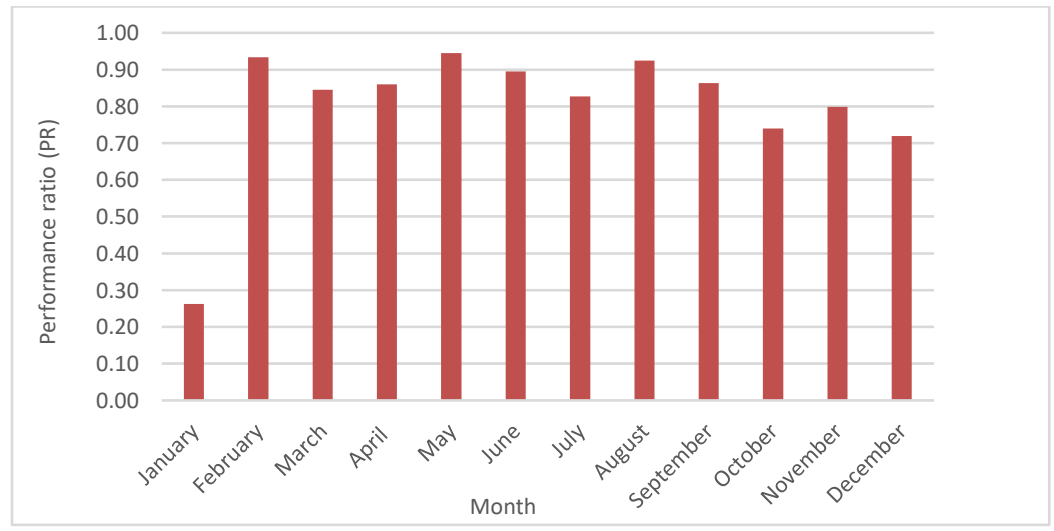

Fig. 7. Monthly averaged PR 
Figure 8 shows monthly variations of capacity factor and overall system efficiency for 2019 . Average annual capacity factor for was $0.142(14.2 \%)$, which varied from 0.022 (2.2\%) in January to 0.239 (23.9 \%) in July. The overall system efficiency of the PV system varied from $0.048(4.8 \%)$ in January to $0.17(17 \%)$ in July with annual average of $0.148(14.8$ $\%)$.

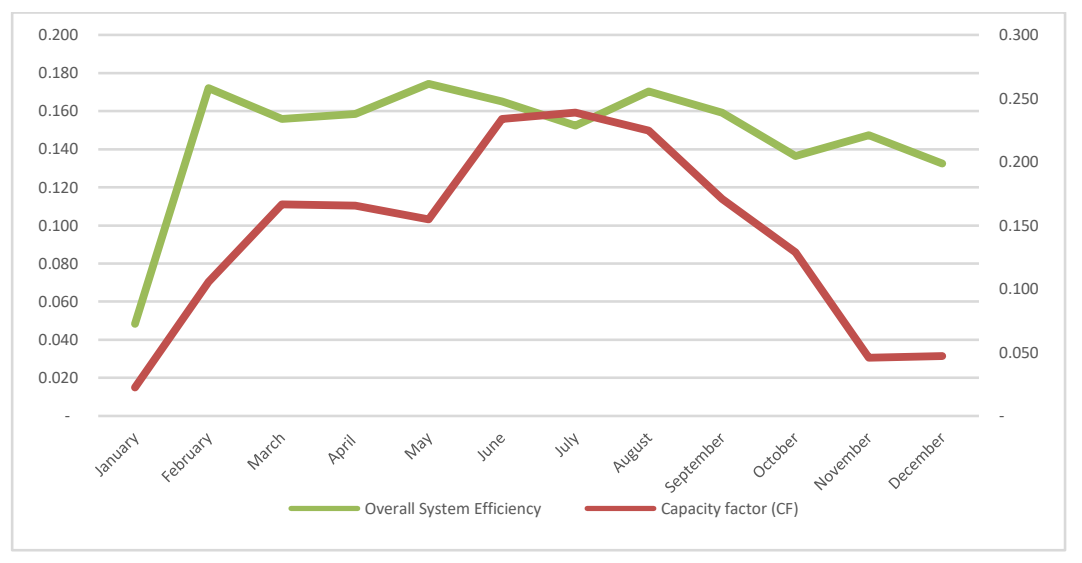

Fig. 8. Monthly variations of PF and $\eta_{\text {sys,m }}$

Figure 9 shows PR for different PV systems around the world, according to analysis in [14].
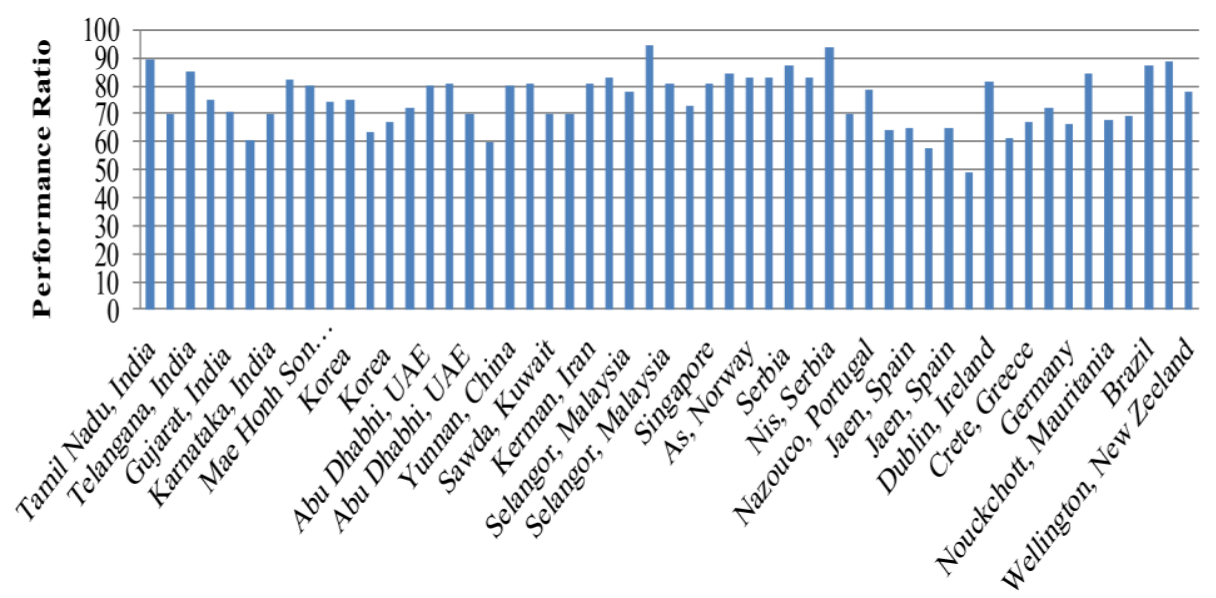

Fig. 9. Performance ratio of the PV system at different plants at different locations of the world [14]

Comparing to PV plants around the world it can be concluded that $50 \mathrm{~kW}$ PV plant in Tomislavgrad has high performance ratio (0.8) and that area of Tomislavgrad has good potential for integration of PV systems.

\section{Conclusion}

The performance analysis of $50 \mathrm{~kW}$ PV plant in Tomislavgrad for 2019 year was carried out. It can be concluded:

- Average of horizontal global irradiation at the location in 2019 was found $4.13 \mathrm{kWh} / \mathrm{m}^{2} /$ day $\left(1.517 .92 \mathrm{kWh} / \mathrm{m}^{2} / \mathrm{day}\right.$ in total).

- The monthly reference yield varied from $63.64 \mathrm{kWh} / \mathrm{kWp}$ to $214.48 \mathrm{kWh} / \mathrm{kWp}$ and the final yield varied from 16.69 $\mathrm{kWh} / \mathrm{kWp}$ to $177.71 \mathrm{kWh} / \mathrm{kWp}$.

- PV plant electricity production in 2019 was $63.126 \mathrm{MWh}(1267.59 \mathrm{kWh} / \mathrm{kWp})$ with monthly variation from 0.813 $\mathrm{kWh}$ (January) to $8.85 \mathrm{kWh}$ (July).

- Average annual performance ratio of the PV plant in 2019 was 0.8 with monthly variations from 0.26 (26\%) in January to $0.92(92 \%)$ in July 2019.

- Average annual capacity factor for was 0.142 (14.2\%), with variations from $0.022(2.2 \%)$ in January to 0.239 (23.9 $\%$ ) in July.

- Average annual overall system efficiency of the PV plant was 0.148 (14.8\%), with variations from $0.048(4.8 \%)$ in January to $0.17(17 \%)$. 
Performance analysis of $50 \mathrm{~kW}$ PV plant in Tomislavgrad shows good potential for integration of PV system in this part of Bosnia and Herzegovina. PR for PV plant in Tomislavgrad would be even higher for similar system with optimal azimuth and optimal PV module tilt $34^{\circ}$ according to calculations in Photovoltaic Geographical Information System (PVGIS). The PV system in Tomislavgrad was installed on the existing facilities so the selection of a more favourable tilt and orientation of the PV modules was not possible, same PV system with optimal tilt ( $34^{\circ}$ for Tomislavgrad) and azimuth $\left(180^{\circ}\right)$ would have better electricity production. Beside optimal tilt and orientation main challenge for location of Tomislavgrad and wider area are the snowfalls in period December to February and they must be considered. For PV systems which are integrated on roofs of buildings, snowfalls can cause lower production and only solution is cleaning the snow. For PV systems which are mounted on ground solution would be to elevate construction from ground (1m or higher, depending on terrain).

The ambient temperature and wind speed are very important parameters for PV system production so the next step in future researching is analyse dependence of electricity production to temperature and wind speed because wind speed measurements are also available for this location. This paper can be useful to engineers and potential investors in this part of Bosnia and Herzegovina by planning and designing future PV systems.

\section{Acknowledgments}

The authors would like to thank to JP Elektroprivreda HZ HB d.d. Mostar for helping in issuing this paper.

\section{References}

[1] Snapshot of Global PV Markets, https://iea-pvps.org/wp-content/uploads/2020/04/IEA_PVPS_Snapshot_2020.pdf Accessed on: 2020-09-15

[2] Report on activities of the State Electricity Regulatory Commission in 2019, State Electricity Regulatory Commission of Bosnia and Herzegovina, https://www.derk.ba/DocumentsPDFs/DERK-Izvjestaj-o-radu-2019en.pdf

[3] http://www.interreg-danube.eu/3smart, (2019). The Danube Transnational Programme, Public presentation event Bosnia and Herzegovina, Accessed on: 2020-09-15

[4] Bakula, M.; Međugorac \& M.; Ćorluka, N. (2019); Microgrid at the location of the EPHZHB business building in Tomislavgrad, 18th International Symposium INFOTEH-JAHORINA, 20-22 March 2019, Available from: https://infoteh.etf.ues.rs.ba/zbornik/2019/radovi/ENS-3/ENS-3-1.pdf

[5] Berin Djikic, Halima Hadziahmetovic, Hamza Cerimovic, Ismira Ahmovic \& Rejhana Blazevic, (2019). Analysis of solar energy potential and optimal panel tilt angle in the area of the city of Sarajevo, 30TH DAAAM International Symposium on Intelligent Manufacturing and Automation, Available from: https://www.daaam.info/Downloads/Pdfs/proceedings/proceedings_2019/030.pdf

[6] IEC, Photovoltaic System Performance Monitoring — Guidelines for Measurement, Data Exchange, and Analysis, IEC Standard 61724, Geneva, Switzerland, 1998

[7] Kumakis E., Kalykakis, S., Papazoglou, T. M., A photovoltaic park's performance on the island of Crete, Journal of Energy : Energija, Vol. 57 No. 3, 2008., Available from: https://hrcak.srce.hr/file/45529

[8] Bhoj Raj Tiwari, Nawraj Bhattarai \& Ajay Kumar Jha, (2019), Performance analysis of a $100 \mathrm{kWp}$ grid connected Solar Photovoltaic Power Plant in Kharipati, Bhaktapur, Nepal, Proceedings of IOE Graduate Conference, 2017, Volume: 5 ISSN: 2350-8914 (Online)

[9] Dragana D. Milosavljević, Dragoljub Lj. Mirjanić, Tomislav M. Pavlović, Darko M. Mirjanić \& Danica S. Piršl, (2015). Energy efficiency of PV solar plant in real climate conditions in Banja Luka, Thermal Science, January 2015 , Available

from: https://www.researchgate.net/publication/276512828_Energy_efficiency_of_PV_solar_plant_in_real_climate_con ditions_in_Banja_Luka/link/568bd21908ae129fb5cb8746/download

[10] Dragana D. Milosavljević, Tomislav M. Pavlović \& Danica S. Piršl (2015). Performance analysis of A gridconnected solar PV plant in Niš, republic of Serbia, Renewable and Sustainable Energy Reviews 44 (2015), pp. 423435

[11] Lutero Carmo de Lima, Leonardo de Araújo Ferreira \& Francisco Hedler Barreto de Lima Morais, (2017). Performance analysis of a grid connected photovoltaic system in northeastern Brazil, Energy for Sustainable Development 37 (2017), pp. 79-85

[12] Kamal Attari, Ali Elyaakoubi \& Adel Asselman, (2016). , Performance analysis and investigation of a gridconnected photovoltaic installation in Morocco, Energy Reports 2 (2016), pp. 261-266

[13] T. M. Pavlović, D. D. Milosavljević, D. Lj. Mirjanić, I. S. Radonjić, L. S. Pantić \& D. Piršl, Analyses of PV systems of $1 \mathrm{~kW}$ electricity generation in Bosnia and Herzegovina (2011), Contemporary Materials (Renewable energy sources), II-2 (2011), Page 123 of 138, Avaliable from: http://www.savremenimaterijali.info/sajt/doc/file/casopisi/2_2/3_pavlovic.pdf

[14] Rachit Srivastava, A.N. Tiwari \& V.K. Giri, An overview on performance of PV plants commissioned at different places in the world, Energy for Sustainable Development Volume 54, February 2020, Pages 51-59

[15] Kipp \& Zonen, Brochure pyranometers, Avaliable from: https://www.kippzonen.com/Download/70/BrochurePyranometers 